\title{
CrimRxiv
}

\section{Governing Delinquency Through Freedom: Control, Rehabilitation and Desistance}

Géraldine Bugnon, Lucy Garnier

Published on: Mar 04, 2022

DOI: $10.21428 / \mathrm{cb} 6 \mathrm{ab} 371.8 \mathrm{~d} 61520 f$

License: Creative Commons Attribution 4.0 International License (CC-BY 4.0). 
